\title{
KOMODITAS PERIKANAN DI PULAU WANGI-WANGI, WAKATOBI
}

\author{
Nanda Radhitia Prasetiawan* \\ Loka Perekayasaan Teknologi Kelautan, BRSDM KP \\ Jl. Ir Soekarno No.3 Desa Patuno Kec. Wangi-Wangi Kab. Wakatobi, Indonesia \\ *Koresponden Penulis: NR.Prasetiawan@gmail.com
}

\begin{abstract}
Abstrak
Pulau Wangi-Wangi sebagai bagian dari Taman Nasional Wakatobi merupakan pusat pemerintahan dan ekonomi di Kabupaten Wakatobi. Keanakeragaman hayati laut dan kultur bahari yang cukup kuat menjadikan sebagian mayarakat pada pulau ini berprofesi sebagai nelayan. Hasil perikanan pun menjadi sumber gizi utama dan komoditas bagi masyarakat. Jenis-jenis komoditas hasil perikanan telah diidentifikasi melalui survei pada pasar-pasar yang ada di pulau Wangi-Wangi. Hasil perikanan yang diperdangangkan didominasi oleh ikan pelagis dan ikan-ikan karang. Adapun ikan-ikan tersebut berasal dari famili Scombridae, Carangidae, Serranidae, Lutjanidae, Haemulidae, Scaridae, Labridae, Lethrinidae, Siganidae, Nemipteridae, Mullidae, Mugilidae, Dasyatidae, Acanturidae, Holocentridae, Balistidae, Atherinidae, Belonidae, Caesionodae, Ephippidae, Ostraciidae, Diodontidae, Coryphaenidae, Zanclidae, Muraenidae yang merupakan hasil tangkapan nelayan tradisional. Beberapa komoditas perikanan lain yang diperdagangkan adalah cumi-cumi, sotong, gurita, Crustacea, Bulu babi (Diadematidae) serta kerangkerangan dan gastropoda laut. Kima (Tridacnidae) juga dapat ditemukan di pasar di pulau Wangi-Wangi. Sebagian besar hasil perikanan diperdangkan dalam bentuk segar, adapun produk lainnya merupakan hasil pengasapan, pengasinan ataupun pengeringan yang ditujukan untuk konsumsi lokal. Pada pasar di pulau Wangi-Wangi nelayan menjual langsung hasil tangkapan ke konsumen ataupun ke pedagang ikan. Pengolahan hasil perikanan di Pulau Wangi-Wangi masih terbatas sehingga perlu adanya diversifikasi produk olahan untuk memberikan nilai tambah pada komoditas hasil perikanan yang ada.
\end{abstract}

Kata Kunci: Carangidae, Chepalopoda, Scombridae, Serranidae, Strombidae

\begin{abstract}
Wangi-Wangi Island as part of Wakatobi National Park is the center of government and economy in Wakatobi Regency. Marine biodiversity and strong marine culture of the society make some people on this island work as fishermen. Fish become the main source of nutrition and commodities for the community. Kind of fish have been identified through surveys on markets on the Wangi-Wangi island. The fish that are traded are dominated by pelagic and reef fish. The fish family are Scombridae, Carangidae, Serranidae, Lutjanidae, Haemulidae, Scaridae, Labridae, Lethrinidae, Siganidae, Nemipteridae, Mullidae, Mugilidae, Dasyatidae, Acanturidae, Holocentride, Osteididae, Osteididae, Osteididae, Osteididae, Oreididae, Oreididae, Oreididae, Oreididae, Oreidae Diodontidae, Coryphaenidae, Zanclidae and Muraenidae which are the catch of traditional fishermen. Some other fisheries commodities traded are squid, cuttlefish, octopus, crustaceans, sea urchins (Diadematidae), bivalvia and gastropods. Tridacnidae also be found in markets. Most of the fishery products are brought in fresh form, while the other products are smoke fish, salted fish or dried fish intended for local consumption. In the markets, fishermen sell their catch directly to consumers or to fish traders. Fish processing on Wangi-Wangi Island is still limited so that there is a need for diversification to provide value added product to existing fishery commodities.
\end{abstract}

Keywords: Carangidae, Chepalopoda, Scombridae, Serranidae, Strombidae

\section{PENDAHULUAN}

Taman Nasional Wakatobi merupakan daerah dengan potensi keanekaragaman hayati yang tergolong tinggi dengan estimasi nilai ekonomi sebagai tempat pertumbuhan ikan sebesar Rp. 400.024.550.999 / tahun dan estimasi nilai manfaat langsung untuk kegiatan perikanan tangkap di Wakatobi Mencapai Rp. 372.208.100.000 / tahun [1] 
[2][3]. Ekosistem karang, lamun dan mangrove pada perairan Wakatobi adalah adalah habitat, lokasi pemijahan dan nursery ground untuk berbagai biota perairan [4][5]. Pada perairan Wakatobi setidaknya dapat ditemukan 300 jenis ikan dari 39 suku [6].

Adapun pulau Wangi-Wangi adalah pulau terbesar di Taman Nasional Wakatobi dengan luas $156,5 \mathrm{~km}^{2}$. Pulau ini merupakan pulau dengan jumlah penduduk terbesar sekaligus sebagai pusat pemerintahan Kabupaten Wakatobi [7][8]. Sebagian besar desa-desa yang ada di pulau ini merupakan desa pesisir (13 desa pesisir di Kec. WangiWangi dan 19 Desa Pesisir di Kec. WangiWangi Selatan) dimana masyarakatnya tinggal pada daerah pantai dan kehidupannya bergantung pada potensi laut [9]. Kultur bahari yang cukup kuat menjadikan sebagian mayarakat pada pulau Wangi-Wangi menggantungkan hidupnya dengan berprofesi sebagai nelayan yang menangkap ikan pada terumbu karang disekitar pulau ataupun melaut untuk menangkap ikan-ikan pelagis pada perairan laut Banda [10][11][12]. Nelayan di pulau Wangi-Wangi merupakan nelayan tradisional yang menggunakan pancing, jaring insang, bubu dan panah untuk menangkap ikan sepanjang tahun [13]. Adapun kegiatan budidaya ikan masih terbatas dan belum banyak berkembang [14]. Pada perairan pulau Wangi-Wangi setidaknya dapat ditemukan 31 famili ikan yang sebagian diataranya merupakan ikan target [6]. Hal tersebut menjadikan sektor perikanan dan kelautan menjadi salah satu penggerak dan penopang perekonomian masyarakat di pulau Wangi-Wangi [12].

Sebagaimana umumnya pada wilayah lain di Kabupaten Wakatobi, berbagai bentuk hasil perikanan yang didominasi oleh hasil laut juga telah menjadi menjadi sumber gizi utama dan komoditas bagi masyarakat pulau Wangi-Wangi [15][16]. Pasar-pasar tradisional di Pulau ini merupakan tempat berkumpulnya hasil tangkapan nelayan dari seluruh bagian pulau dan tempat terjadinya transaksi jual beli [17]. Makalah ini mendeskripsikan jenis-jenis hasil laut sebagai komoditas di Pulau Wangi-Wangi, Wakatobi.

\section{MATERI DAN METODE}

Penelitain dilakukan menggunakan metode survei dengan random sampling sederhana terhadap para padagang ikan yang ada pada 3 pasar tradisional yang terdapat di pulau Wangi-Wangi Kabupaten Wakatobi yaitu Pasar Sentral, Pasar Pagi dan Pasar Pelangi Marina / Pasar Malam (Gambar 1). Pengambilan data dilakukan pada periode Juli 2019 hingga September 2019.

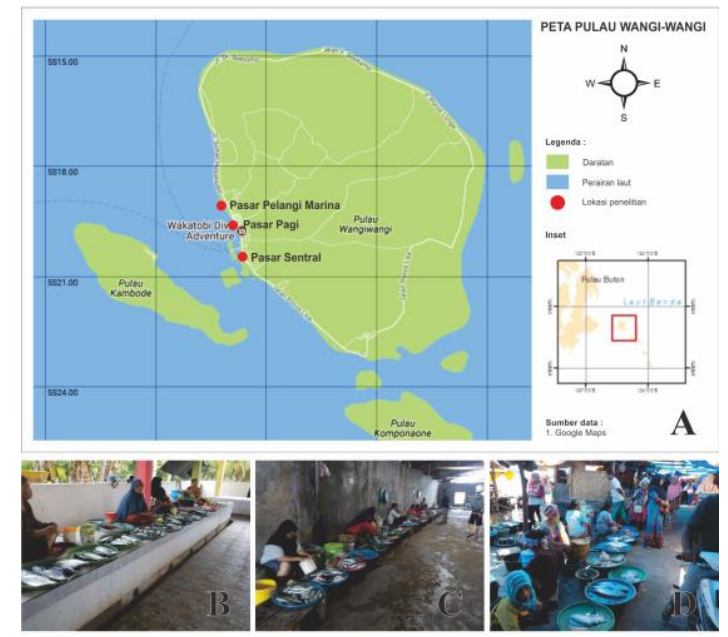

Gambar 1. (A) Peta lokasi penelitian (sumber: Google Map, 2019); (B) Pasar Pelangi Marina / Pasar Malam; (C) Pasar Pagi; (D) Pasar Sentral Wakatobi.

Jenis-jenis komoditas perikanan yang ditemukan pada ketiga pasar tersebut dicatat, didokumentasikan dengan kamera dan diidentifikasi dengan buku petunjuk identifikasi [18][19][20][21][22][23][24]. Komposisi famili ikan yang ditemukan di pasar dihitung dan dinyatakan dalam persentase. Berdasarkan ketersediaannya komoditas perikanan tersebut dikategorikan kedalam 4 kategori yaitu: umum ditemukan (UD), dapat ditemukan (DD), jarang ditemukan (JD), sangat jarang ditemukan (SJD). Sedangkan berdasarkan bentuknya, komoditas perikanan tersebut dikategorikan menjadi utuh (U), potongan (P) dan olahan (O). Adapun berdasarkan kesegarannya komoditas perikanan tersebut dikategorikan kedalam 3 kategori yaitu: hidup $(\mathrm{H})$, segar $(\mathrm{S})$ dan tidak segar (TS). 


\section{HASIL DAN PEMBAHASAN}

Hasil-hasil perikanan laut merupakan komoditas utama bagi Kabupaten Wakatobi [25]. Adapun komoditas perikanan di Pulau Wangi-Wangi didominasi oleh ikan-ikan pelagis dan ikan-ikan karang (Gambar 2).

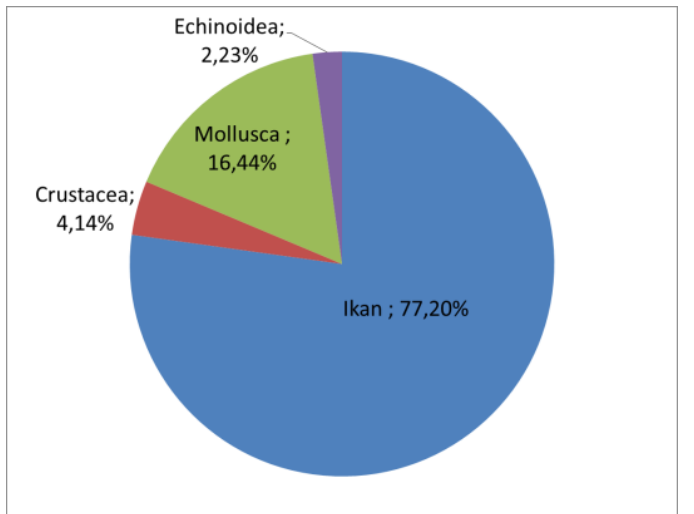

Gambar 2. Komposisi komoditas perikanan pada pasar-pasar di pulau Wangi-Wangi

Beberapa komoditas lain yang umum ataupun dapat ditemukan pada pasar-pasar di pulau Wangi-Wangi adalah Chepalopoda (cumi-cumi, sotong, dan gurita), Gastropoda laut, Bivalvia, Crustacea, Diadematidae (bulu babi), cacing laut dari genus Siphonosoma dan rumput laut. Komoditas tersebut sebagian besar merupakan hasil perikanan tangkap dan diperdagangkan dalam bentuk segar. Hasilhasil laut yang diperdagangkan tersebut umum dikonsumsi oleh masyarat pada daerah pesisir dan wilayah kepulauan [26][27][28][16][18].

\section{Ikan}

Setidaknya dapat ditemukan 126 janis ikan pada pasar-pasar di pulau Wangi-Wangi. Ikan merupakan komoditas yang dapat tersedia sepanjang tahun. Seluruh ikan tersebut diperuntukkan sebagai bahan pangan. Scrombidae dan Carangidae adalah famili ikan yang paling banyak dan umum ditemukan (Gambar 3).

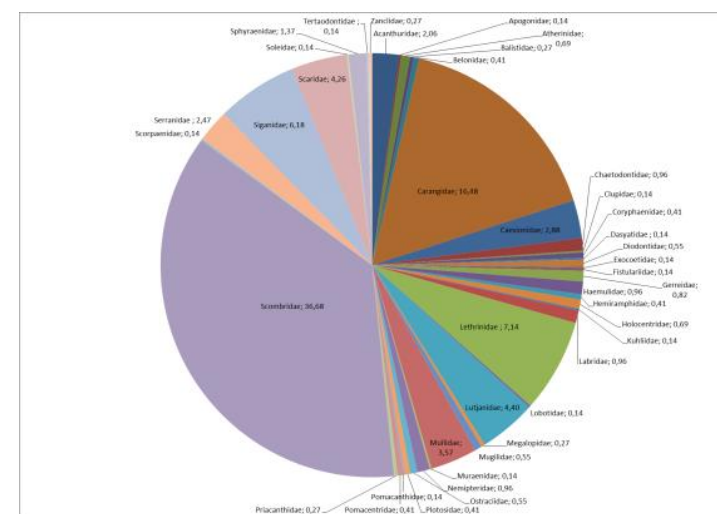

Gambar 3. Komposisi komoditas ikan berdasarkan famili pada pasar-pasar di pulau Wangi-Wangi

Tuna, cakalang serta kwee menjadi salah satu komoditas penting yang digemari oleh masyarakat [29][25]. Selain diperuntukkan untuk konsumsi lokal, ikan tuna berukuran besar juga dijual keluar Wakatobi melalui pedagang pengumpul [30]. Beberapa ikan pelagis kecil yang umum dan banyak ditemukan pada pasar-pasar di pulau Wangi-Wangi adalah Decapterus sp., Auxis thazard dan Rastrelliger kanagurta. Ikan-ikan pelagis tersebut merupakan hasil tangkapan harian nelayan tradisional pada perairan laut Banda di sekitar kepulauan Wakatobi dengan menggunakan pancing ataupun pancing rawai serta purse seine pada sekitar rumpon [31]. Sebagaimana diketahui sebagian nelayan di pulau Wangi-Wangi mengkhususkan profesinya sebagai nelayan tuna [32].

Tabel 1. Jenis-jenis ikan pada pasar-pasar di pulau Wangi-Wangi dan ketersediannya.

\begin{tabular}{ll}
\hline Famili / Jenis & Ketersediaan \\
\hline Acanthuridae & $\mathrm{DD}, \mathrm{U}, \mathrm{S}$ \\
Acanthurus olivaceus & $\mathrm{JD}, \mathrm{U}, \mathrm{S}$ \\
Acanthurus triostegus & $\mathrm{DD}, \mathrm{U}, \mathrm{S}$ \\
Acanthurus xanthopterus & $\mathrm{DD}, \mathrm{U}, \mathrm{S}$ \\
$\begin{array}{l}\text { Acanthurus } \text { sp. } \\
\text { Naso } \text { sp. }\end{array}$ & $\mathrm{DD}, \mathrm{U}, \mathrm{S}$ \\
$\begin{array}{l}\text { Apogonidae } \\
\text { Sphaeramia orbicularis }\end{array}$ & $\mathrm{SJD}, \mathrm{U}, \mathrm{S}$ \\
$\begin{array}{l}\text { Atherinidae } \\
\text { Atherinomorus } \text { sp. }\end{array}$ & $\mathrm{DD}, \mathrm{U}, \mathrm{S}$ \\
$\begin{array}{l}\text { Balistidae } \\
\text { Melichthys sp. }\end{array}$ & $\mathrm{DD}, \mathrm{U}, \mathrm{S}$ \\
$\begin{array}{l}\text { Pseudobalistes flavimarginatus } \\
\text { Rhinecanthus verrucosus }\end{array}$ & $\mathrm{DD}, \mathrm{U}, \mathrm{S}$ \\
& $\mathrm{DD}, \mathrm{U}, \mathrm{S}$ \\
\hline
\end{tabular}


Lanjutan Tabel 1. . Jenis-jenis ikan pada pasarpasar di pulau Wangi-Wangi dan ketersediannya

\begin{tabular}{|c|c|}
\hline Famili / Jenis & Ketersediaan \\
\hline \multicolumn{2}{|l|}{ Belonidae } \\
\hline Ablennes hians & $\mathrm{DD}, \mathrm{U}, \mathrm{S}$ \\
\hline \multicolumn{2}{|l|}{ Carangidae } \\
\hline Caranx ignobilis & $\mathrm{UD}, \mathrm{U} / \mathrm{P}, \mathrm{S}$ \\
\hline Caranx sp. & $\mathrm{UD}, \mathrm{U} / \mathrm{P}, \mathrm{S}$ \\
\hline Decapterus sp. & $\mathrm{UD}, \mathrm{U}, \mathrm{S}$ \\
\hline Selar sp. & $\mathrm{UD}, \mathrm{U}, \mathrm{S}$ \\
\hline \multicolumn{2}{|l|}{ Caesionidae } \\
\hline Caesio cuning & $\mathrm{UD}, \mathrm{U}, \mathrm{S}$ \\
\hline Caesio caerulaurea & $\mathrm{UD}, \mathrm{U}, \mathrm{S}$ \\
\hline Caesio lunaris & $\mathrm{UD}, \mathrm{U}, \mathrm{S}$ \\
\hline Caesio teres & $\mathrm{UD}, \mathrm{U}, \mathrm{S}$ \\
\hline \multicolumn{2}{|l|}{ Chaetodontidae } \\
\hline Chaetodon klenii & $\mathrm{DD}, \mathrm{U}, \mathrm{S}$ \\
\hline Chaetodon vagabundus & $\mathrm{JD}, \mathrm{U}, \mathrm{S}$ \\
\hline Chaetodon mayersi & $\mathrm{JD}, \mathrm{U}, \mathrm{S}$ \\
\hline Chaetodon melannotus & $\mathrm{JD}, \mathrm{U}, \mathrm{S}$ \\
\hline Chaetodon lunulatus & $\mathrm{JD}, \mathrm{U}, \mathrm{S}$ \\
\hline Chaetodon unimaculatus & $\mathrm{JD}, \mathrm{U}, \mathrm{S}$ \\
\hline Chaetodon speculum & $\mathrm{JD}, \mathrm{U}, \mathrm{S}$ \\
\hline \multicolumn{2}{|l|}{ Clupidae } \\
\hline Sardinella sp. & $\mathrm{DD}, \mathrm{U}, \mathrm{S}$ \\
\hline \multicolumn{2}{|l|}{ Coryphaenidae } \\
\hline Coryphaena hippurus & $\mathrm{DD}, \mathrm{U}, \mathrm{S}$ \\
\hline \multicolumn{2}{|l|}{ Dasyatidae } \\
\hline Taeniura lymma & $\mathrm{JD}, \mathrm{U}, \mathrm{S}$ \\
\hline \multicolumn{2}{|l|}{ Diodontidae } \\
\hline Diodon holocanthus & $\mathrm{JD}, \mathrm{U}, \mathrm{S}$ \\
\hline Diodon liturosus & $\mathrm{JD}, \mathrm{U}, \mathrm{S}$ \\
\hline \multicolumn{2}{|l|}{ Exocoetidae } \\
\hline Cheilopogon sp. & $\mathrm{DD}, \mathrm{U}, \mathrm{S}$ \\
\hline \multicolumn{2}{|l|}{ Fistulariidae } \\
\hline Fistularia commersonii & $\mathrm{JD}, \mathrm{U}, \mathrm{S}$ \\
\hline \multicolumn{2}{|l|}{ Gerreidae } \\
\hline Gerres sp. & $\mathrm{DD}, \mathrm{U}, \mathrm{S}$ \\
\hline \multicolumn{2}{|l|}{ Haemulidae } \\
\hline Plectorhinchus chaetodonoides & $\mathrm{DD}, \mathrm{U}, \mathrm{S}$ \\
\hline Plectorinchus lineatus & $\mathrm{DD}, \mathrm{U}, \mathrm{S}$ \\
\hline Plectorinchus vittatus & $\mathrm{DD}, \mathrm{U}, \mathrm{S}$ \\
\hline \multicolumn{2}{|l|}{ Hemiramphidae } \\
\hline Hyporhamphus sp. & $\mathrm{DD}, \mathrm{U}, \mathrm{S}$ \\
\hline \multicolumn{2}{|l|}{ Holocentridae } \\
\hline Beryx sp. & $\mathrm{DD}, \mathrm{U}, \mathrm{S}$ \\
\hline Myripristis hexagona & $\mathrm{DD}, \mathrm{U}, \mathrm{S}$ \\
\hline Myripristis sp. & $\mathrm{DD}, \mathrm{U}, \mathrm{S}$ \\
\hline \multicolumn{2}{|l|}{ Kuhlidae } \\
\hline Kuhlia mugil & $\mathrm{DD}, \mathrm{U}, \mathrm{S}$ \\
\hline \multicolumn{2}{|l|}{ Labridae } \\
\hline Choerodon anchorago & $\mathrm{DD}, \mathrm{U}, \mathrm{S}$ \\
\hline Cheilinus fasciatus & $\mathrm{DD}, \mathrm{U}, \mathrm{S}$ \\
\hline \multicolumn{2}{|l|}{ Lethrinidae } \\
\hline Gnathodentex aureolineatus & $\mathrm{DD}, \mathrm{U}, \mathrm{S}$ \\
\hline Gymnocranius sp. & $\mathrm{DD}, \mathrm{U}, \mathrm{S}$ \\
\hline Lethrinus atkinsoni & $\mathrm{DD}, \mathrm{U}, \mathrm{S}$ \\
\hline Lethrinus harak & $\mathrm{DD}, \mathrm{U}, \mathrm{S}$ \\
\hline Lethrinus microdon & $\mathrm{DD}, \mathrm{U}, \mathrm{S}$ \\
\hline Lethrinus ornatus & $\mathrm{DD}, \mathrm{U}, \mathrm{S}$ \\
\hline Lethrinus sp. & $\mathrm{DD}, \mathrm{U}, \mathrm{S}$ \\
\hline
\end{tabular}

Lanjutan Tabel 1. .Jenis-jenis ikan pada pasarpasar di pulau Wangi-Wangi dan ketersediannya

\begin{tabular}{|c|c|}
\hline Famili / Jenis & Ketersediaan \\
\hline \multicolumn{2}{|l|}{ Lobotidae } \\
\hline Lobotes sp. & $\mathrm{DD}, \mathrm{U}, \mathrm{S}$ \\
\hline \multicolumn{2}{|l|}{ Lutjanidae } \\
\hline Etelis sp. & $\mathrm{DD}, \mathrm{U}, \mathrm{S}$ \\
\hline Lutjanus bengalensis & $\mathrm{DD}, \mathrm{U}, \mathrm{S}$ \\
\hline Lutjanus bohar & $\mathrm{DD}, \mathrm{U}, \mathrm{S}$ \\
\hline Lutjanus carponotatus & $\mathrm{DD}, \mathrm{U}, \mathrm{S}$ \\
\hline Lutjanus decussatus & $\mathrm{DD}, \mathrm{U}, \mathrm{S}$ \\
\hline Lutjanus boutton & $\mathrm{DD}, \mathrm{U}, \mathrm{S}$ \\
\hline Lutjanus ehrenbergii & $\mathrm{DD}, \mathrm{U}, \mathrm{S}$ \\
\hline Lutjanus gibbus & $\mathrm{DD}, \mathrm{U}, \mathrm{S}$ \\
\hline Lutjanus madras & $\mathrm{DD}, \mathrm{U}, \mathrm{S}$ \\
\hline Lutjanus rufolineatus & $\mathrm{DD}, \mathrm{U}, \mathrm{S}$ \\
\hline Lutjanus russellii & $\mathrm{DD}, \mathrm{U}, \mathrm{S}$ \\
\hline Lutjanus fulvus & $\mathrm{DD}, \mathrm{U}, \mathrm{S}$ \\
\hline Macolor macularis & $\mathrm{DD}, \mathrm{U}, \mathrm{S}$ \\
\hline Pristipomoides sp. & $\mathrm{DD}, \mathrm{U}, \mathrm{S}$ \\
\hline Symphorichthys spilurus & $\mathrm{DD}, \mathrm{U}, \mathrm{S}$ \\
\hline \multicolumn{2}{|l|}{ Megalopidae } \\
\hline Megalops cyprinoides & $\mathrm{DD}, \mathrm{U}, \mathrm{S}$ \\
\hline \multicolumn{2}{|l|}{ Mugilidae } \\
\hline Chelon sp. & $\mathrm{DD}, \mathrm{U}, \mathrm{S}$ \\
\hline Crenemugil sp. & $\mathrm{DD}, \mathrm{U}, \mathrm{S}$ \\
\hline \multicolumn{2}{|l|}{ Mullidae } \\
\hline Mulloidichthys flavolineatus & $\mathrm{DD}, \mathrm{U}, \mathrm{S}$ \\
\hline Mulloidichthys vanicolensis & $\mathrm{DD}, \mathrm{U}, \mathrm{S}$ \\
\hline Parupeneus berberinus & $\mathrm{DD}, \mathrm{U}, \mathrm{S}$ \\
\hline Parupeneus sp. & $\mathrm{DD}, \mathrm{U}, \mathrm{S}$ \\
\hline Upeneus moluccensis & $\mathrm{DD}, \mathrm{U}, \mathrm{S}$ \\
\hline \multicolumn{2}{|l|}{ Muraenidae } \\
\hline Gymnothorax undulatus & $\mathrm{JD}, \mathrm{U} / \mathrm{P}, \mathrm{S}$ \\
\hline Gymnothorax sp. & $\mathrm{SJD}, \mathrm{U} / \mathrm{P}, \mathrm{S}$ \\
\hline \multicolumn{2}{|l|}{ Nemipteridae } \\
\hline Scolopsis lineatus & $\mathrm{DD}, \mathrm{U}, \mathrm{S}$ \\
\hline Scolopsis temporalis & $\mathrm{DD}, \mathrm{U}, \mathrm{S}$ \\
\hline \multicolumn{2}{|l|}{ Ostraciidae } \\
\hline Lactoria cornuta & JD, U, S \\
\hline Ostracion meleagris & $\mathrm{JD}, \mathrm{U}, \mathrm{S}$ \\
\hline Ostracion sp. & $\mathrm{JD}, \mathrm{U}, \mathrm{S}$ \\
\hline \multicolumn{2}{|l|}{ Plotosidae } \\
\hline Plotosus lineatus & $\mathrm{DD}, \mathrm{U}, \mathrm{S}$ \\
\hline \multicolumn{2}{|l|}{ Pomacanthidae } \\
\hline Pomacanthus imperator & JD, U, S \\
\hline \multicolumn{2}{|l|}{ Pomacentridae } \\
\hline Abudefduf vaigiensis & $\mathrm{DD}, \mathrm{U}, \mathrm{S}$ \\
\hline Amblyglyphidodon curacao & $\mathrm{DD}, \mathrm{U}, \mathrm{S}$ \\
\hline \multicolumn{2}{|l|}{ Priacanthidae } \\
\hline Priacanthus sp. & $\mathrm{DD}, \mathrm{U}, \mathrm{S}$ \\
\hline \multicolumn{2}{|l|}{ Scombridae } \\
\hline Auxis thazard & $\mathrm{UD}, \mathrm{U}, \mathrm{S}$ \\
\hline Euthynnus affinis & $\mathrm{DD}, \mathrm{U}, \mathrm{S}$ \\
\hline Katsuonus pelamis & $\mathrm{UD}, \mathrm{U} / \mathrm{P}, \mathrm{S}$ \\
\hline Rastrelliger kanagurta & $\mathrm{UD}, \mathrm{U}, \mathrm{S}$ \\
\hline Rastrelliger $\mathrm{sp}$. & $\mathrm{UD}, \mathrm{U}, \mathrm{S}$ \\
\hline Thunnus albaceres & $\mathrm{UD}, \mathrm{U} / \mathrm{P}, \mathrm{S}$ \\
\hline Thunnus sp. & $\mathrm{UD}, \mathrm{U} / \mathrm{P}, \mathrm{S}$ \\
\hline \multicolumn{2}{|l|}{ Scorpaenidae } \\
\hline Pontinus sp. & SJD, U, S \\
\hline
\end{tabular}


Lanjutan Tabel 1. .Jenis-jenis ikan pada pasarpasar di pulau Wangi-Wangi dan ketersediannya

\begin{tabular}{ll}
\hline Famili / jenis & Ketersediaan \\
\hline Serranidae & \\
Aethaloperca rogaa & DD, U, S \\
Cephalopholis igarashiensis & JD, U, S \\
Cephalopholis miniata & $\mathrm{UD}, \mathrm{U}, \mathrm{S}$ \\
Cephalopholis polleni & $\mathrm{DD}, \mathrm{U}, \mathrm{S}$ \\
Epinephelus coioides & $\mathrm{DD}, \mathrm{U}, \mathrm{S}$ \\
Epinephelus fuscoguttatus & $\mathrm{DD}, \mathrm{U}, \mathrm{S}$ \\
Epinephelus howlandi & $\mathrm{DD}, \mathrm{U}, \mathrm{S}$ \\
Epinephelus macrospilos & $\mathrm{DD}, \mathrm{U}, \mathrm{S}$ \\
Epinephelus merra & $\mathrm{UD}, \mathrm{U}, \mathrm{S}$ \\
Epinephelus quoyanus & $\mathrm{DD}, \mathrm{U}, \mathrm{S}$ \\
Epinephelus sexfaciatus & $\mathrm{UD}, \mathrm{U}, \mathrm{S}$ \\
Siganidae & \\
Siganus canalicuatus & $\mathrm{UD}, \mathrm{U}, \mathrm{S}$ \\
Siganus doliatus & $\mathrm{DD}, \mathrm{U}, \mathrm{S}$ \\
Siganus guttatus & $\mathrm{UD}, \mathrm{U}, \mathrm{S}$ \\
Siganus puellus & $\mathrm{DD}, \mathrm{U}, \mathrm{S}$ \\
Siganus punctatus & $\mathrm{DD}, \mathrm{U}, \mathrm{S}$ \\
Siganus unimaculatus & $\mathrm{JD}, \mathrm{U}, \mathrm{S}$ \\
Siganus vulpinus & $\mathrm{DD}, \mathrm{U}, \mathrm{S}$ \\
Siganus sp. & $\mathrm{DD}, \mathrm{U}, \mathrm{S}$ \\
Scaridae & \\
Chlorurus microrhinos & $\mathrm{DD}, \mathrm{U}, \mathrm{S}$ \\
Chlorurus sp. & $\mathrm{DD}, \mathrm{U}, \mathrm{S}$ \\
Hipposcarus longiceps & $\mathrm{DD}, \mathrm{U}, \mathrm{S}$ \\
Scarus progsiognathos & $\mathrm{DD}, \mathrm{U}, \mathrm{S}$ \\
Scarus rivulatus & $\mathrm{DD}, \mathrm{U}, \mathrm{S}$ \\
Scarus rubroviolaceus & $\mathrm{DD}, \mathrm{U}, \mathrm{S}$ \\
Scarus schlegeli & $\mathrm{DD}, \mathrm{U}, \mathrm{S}$ \\
Scarus sp. & $\mathrm{DD}, \mathrm{U}, \mathrm{S}$ \\
Soleidae & $\mathrm{JD}, \mathrm{U}, \mathrm{S} / \mathrm{H}$ \\
Synaptura marginata & \\
Sphyraenidae & $\mathrm{UD}, \mathrm{U}, \mathrm{S}$ \\
Sphyraena sp. & \\
Tetraodontidae & $\mathrm{JD}, \mathrm{U}, \mathrm{S}$ \\
Arothron reticularis & \\
Zanclidae & $\mathrm{JD}, \mathrm{U}, \mathrm{S}$ \\
Zanclus cornutus & \\
&
\end{tabular}

Lethrinidae, Siganidae, Lutjanidae, Scaridae, Mullidae, Caesionidae, Serranidae dan Haemulidae adalah famili ikan-ikan karang yang dapat ditemukan pada pasarpasar dipulau Wangi-Wangi. Ikan-ikan tersebut umumnya diperdagangkan dalam kondisi segar dan utuh. Lutjanidae, Serranidae dan Haemulidae merupakan ikan-ikan karang yang tergolong ekonomis penting di pulau Wangi-Wangi [31][33]. Selain ikan-ikan target yang umum ditangkap oleh nelayan, pada pasar di pulau Wangi-Wangi juga dapat ditemukan ikan-ikan Chaetodon yang merupakan ikan indikator kesehatan terumbu karang dan beberapa jenis ikan mayor seperti Zanclus cornutus dan Sphaeramia orbicularis.
Ikan-ikan karang tersebut umumnya merupakan hasil tangkapan pada habitat karang, lamun dan atol karang di sekitar perairan Wakatobi dengan pancing, panah dan perangkap ikan [34].

Ikan-ikan berukuran kecil umumnya diperdagangkan dalam bentuk utuh dengan kondisi segar. Adapun ikan ikan berukuran besar seperti tuna, kwee, cakalang, kakaktua, kakap dan kerapu dapat diperdagangkan dalam bentuk utuh ataupun potongan daging dengan kondisi segar.

\section{Mollusca}

Selain ikan, Mollusca laut adalah komoditas lain yang juga dapat ditemukan pada pasar-pasar di Pulau Wangi-Wangi. Cumi-cumi, sotong dan gurita dalam berbagai ukuran dapat tersedia dan melimpah pada waktu-waktu tertentu. Cumi-cumi yang berukuran kecil diperdagangkan dalam bentuk utuh segar, sedangkan sotong yang berukuran besar dijual dalam bentuk utuh ataupun potongan daging. Adapun gurita diperdagangkan dalam kondisi segar ataupun telah dikeringkan.

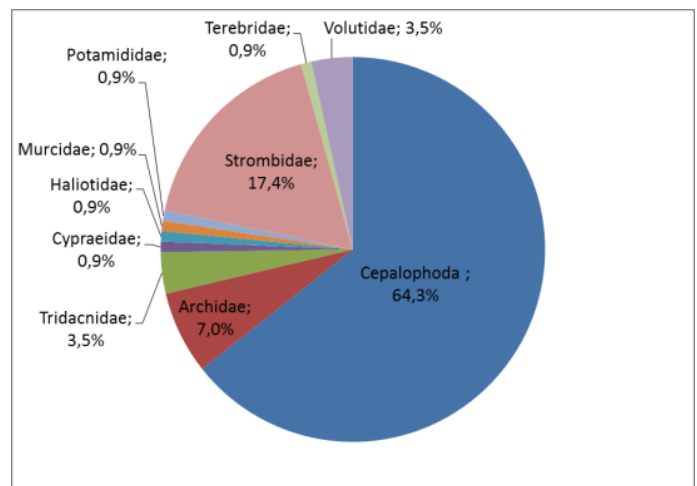

Gambar 4. Komposisi komoditas Mollusca pada pasar-pasar di pulau Wangi-Wangi

Setidaknya terdapat 14 jenis Gastropoda dan Bivalvia laut yang dapat ditemukan di pasar-pasar di pulau Wangi-Wangi (Tabel 2). Adapun Strombus luhuanus adalah Gastropoda laut yang paling sering ditemukan. Gastropoda jenis ini umum dijadikan sebagai makanan khususnya pada wilayah pesisir Indonesia bagian tengah dan timur [35][36]. Sedangkan Bivalvia yang umum ditemui adalah Anadara sp. 
Gastropoda laut umumnya dijual bersama dengan cangkangnya dan dikumpulkan dalam satu tumpukan jenis yang sama. Sedangkan Bivalvia diperdagangkan utuh dengan cangkangya ataupun dalam bentuk kupas dimana daging telah dipisahkan dari cangkangnya. Penjualan campuran berbagai jenis Gastropoda dan Bivalvia dapat ditemukan ketika tangkapan terbatas ataupun berupa campuran berisikan jenis-jenis yang jarang didapati. Gastropoda dan Bivalvia laut yang diperdagangkan di pasar-pasar merupakan hasil tangkapan nelayan pasang surut dengan cara memungunataupun mengambil langung pada zona intertidal ketika perairan surut [37].

Tabel 2. Jenis-Jenis Gastropoda dan Bivalvia pada pasar-pasar di pulau Wangi-Wangi dan ketersediaanya.

\begin{tabular}{lll}
\hline Famili & Jenis & Ketersedian \\
\hline Arachidae & Anadara sp. & UD, U/K, S/H \\
Tridacnidae & Tridacna sp. & DD, K, S \\
Cypraeidae & Cypraea tigris & JD, U, S \\
Haliotidae & Haliotis sp. & SJD, U, S \\
Muricidae & Chicoreus sp. & SJD, U, S/H \\
Potamididae & Telescopium & SJD, U, S \\
& telescopium & \\
Strombidae & Lambis lambis & UD, U, K. S/H \\
& Lambis sp. & UD, U, K. S/H \\
& Strombus gibberelus & UD, U, K. S/H \\
& Strombus luhuanus & UD, U, K. S/H \\
& Strombus & UD, U, K. S/H \\
& lentiginosus & \\
& Strombus urceus & UD, U, K. S/H \\
Terebridae & Conus marmoreus & SJD, U, S \\
Volutidae & Cymbiola vespertilo & DD, U, K. S/H \\
\hline
\end{tabular}

\section{Crustacea}

Rajungan, udang mantis, udang, kepiting bakau dan lobster merupakan beberapa jenis Crustacea yang dapat ditemukan di pasar-pasar di pulau WangiWangi. Adapun Rajungan adalah Crustacea yang paling sering ditemukan, sedangkan udang mantis, udang, kepiting bakau dan lobster cenderung jarang untuk ditemukan dan tersedia pada waktu-waktu tertentu. Beberapa Crustacea tersebut dapat ditemukan dalam kondisi hidup saat diperdagangkan.

\section{Bulu Babi (Echinoidea)}

Setidaknya terdapat dua jenis bulu babi yang dikonsumsi dan diperdagangkan di Pulau Wangi-Wangi yaitu bulu babi berduri panjang (Diadema setosum) dan pendek. Adapun bagian yang dikonsumsi adalah gonad [38]. Bulu babi diperdagangkan dalam bentuk segar dalam bentuk utuh dan kumpulan gonad yang telah dikumpulkan ke dalam satu cangkang ataupun dikemas dalam botol. Bulu babi tersebut diperoleh dari pengumpulan oleh nelayan pada zona intertidal ketika perairan surut.

\section{Rumput Laut}

Bagian selatan pulau Wangi-Wangi merupakan daerah budidaya rumput laut jenis Eucheuma cottonii dan Eucheuma spinosum [39][40]. Rumput laut tersebut diperdagangkan dalam bentuk kering untuk dikirim keluar Wakatobi melalui pengumpul. Rumput laut hasil budidaya tersebut tidak diperjual belikan di pasar-pasar lokal yang ada di pulau Wangi-Wangi mengingat keduanya ditujukan sebagai bahan baku industri yang memerlukan pengolahan lebih lanjut dan tidak untuk dikonsumsi langsung. Adapun jenis rumput laut yang dapat ditemukan di pasarpasar adalah Caulerpa lentillifera. Rumput laut jenis ini jarang ditemukan di pasar-pasar tetapi umum dikonsumsi oleh masyarakat dalam bentuk segar [41].

\section{Komoditas Hasil Pengolahan}

Selain dalam bentuk segar, beberapa hasil perikanan di pulau Wangi-Wangi diperdagangkan dalam bentuk olahan hasil pengeringan/pengasinan dan pengasapan. Hasil perikanan yang diolah dengan pengeringan diantaranya adalah ikan-ikan karang, cumi-cumi, gurita dan kerang. Sedangkan hasil laut yang diolah dengan cara pengasapan adalah ikan-ikan pelagis terutama tuna dan cakalang serta berbagai jenis ikan karang.

\section{Harga}

Komoditas hasil perikanan pada pasarpasar yang ditujukan untuk konsumsi lokal di pulau Wangi-Wangi tidak diperjual belikan 
dengan cara ditimbang atau dalam ukuran berat $(\mathrm{kg})$ melainkan dalam takaran tumpukan ikan (untuk ikan berukuran kecil) ataupun satuan ekor (untuk ikan-ikan berukuran sedang atau besar). Umumnya ikan-ikan segar yang diperdagangkan di pasar-pasar di pulau Wangi-Wangi dijual dengan harga mulai $\mathrm{Rp}$. 10.000 , Rp. 20.000, Rp. 25.000 ataupun Rp. 50.000 untuk satu tumpukan jenis ikan tertentu. Harga Rp. 10.000 umum ditemukan untuk ikan-ikan berukuran kecil seperti Decapterus sp., Auxis thazard, cumi-cumi ukuran kecil pada saat tangkapan melimpah dan satu takar mangkuk ikan Atherinomorus sp. Harga Rp. 20.000 dan Rp. 25.000 umum ditemukan untuk ikan Rastrelliger kanagurta, Selar sp., tuna ukuran kecil, potongan daging tuna/caklang dan ikan-ikan karang berukuran ukuran kecil. Adapun harga Rp. 50.000 umum ditemukan untuk ikan-ikan karang dan tuna ataupun cakalang berukuran sedang. Sedangkan ikan tuna, cakalang ataupun ikan karang berukuran besar dijual dengan harga diatas Rp. 50.000. Selain itu kadang-kdang juga dapat ditemukan tumpukan campuran ikan Balistidae, Acanthuridae, Chaetodontidae, Zanclidae ataupun ikan karng lain berukuran kecil dalam jumlah kecil yang dijual dengan harga Rp. 5.000 hingga Rp. 10.000

Adapun gastropoda dan bivalvia diperdagangkan dengan harga Rp. 10.000 hingga Rp. 20.000 untuk satu tumpuk. Bulu babi diperdagangkan dengan kisaran harga Rp. 10.000 - Rp. 20.000 untuk satu tumpuk ataupun satu wadah gonad yang telah dikumpulkan. Ikan kering dijual dengan harga mulai Rp. 15.000 untuk jenis ikan ekonomis rendah seperti julung-julung hingga Rp.100.000 atau lebih untuk ikan-ikan ekonomis tinggi seperti kerapu ataupun kakap berukuran besar. Sedangkan hasil pengasapan dijual mulai Rp.10.000 untuk potongan ikan tuna atau cakalang serta Rp. 15.000 hingga Rp. 25.000 untuk ikan-ikan karang. Fluktuasi harga menyesuaikan kelimpahan hasil tangkapan nelayan.

\section{Saluran Pemasaran}

Pasar-pasar di Pulau Wangi-Wangi merupakan tempat bertemunya dan terjadinya transaksi jual beli antara nelayan, pedagang pengecer, pedagang pengumpul dan konsumen [17].

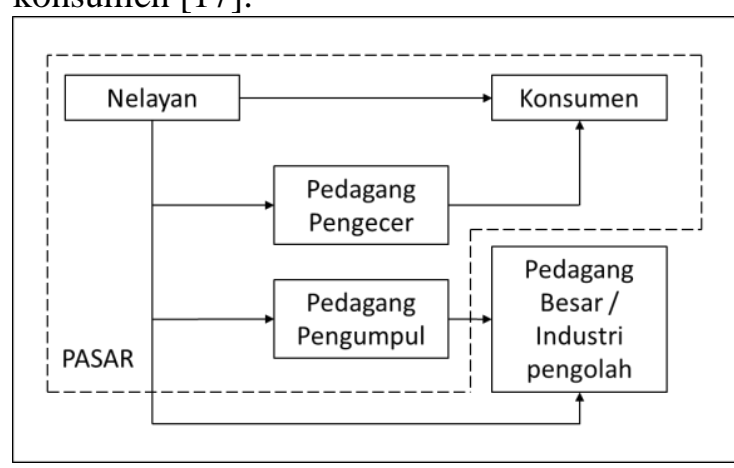

Gambar 5. Saluran pemasaran komoditas perikanan pada pasar-pasar di Pulau WangiWangi.

Adapun sebagian besar komoditas perikanan yang diperdangangkan lebih ditujukan untuk konsumsi pasar lokal. Terdapat beberapa pola saluran pemasaran komoditas perikanan yang terdapat di pulau Wangi-Wangi (Gambar 5) yaitu:

1) Nelayan atau istri nelayan membawa hasil tangkapan dan memasarkannya langsung ke konsumen di pasar-pasar. Transaksi jual beli dengan pola ini umumnya dilakukan untuk ikan-ikan berukuran kecil atau sedang yang merupakan tangkapan harian dari nelayanserta ditujukan untuk konsumsi lokal

2) Nelayan atau istri nelayan menjual hasil tangkapan kepada padagang pengecer di pasar untuk dijual kembali ke konsumen. Transaksi jual beli dengan pola ini umumnya juga dilakukan untuk ikan-ikan berukuran kecil atau sedang.

3) Pedagang pengumpul membeli hasil tangkapan nelayan di pasar untuk kemudian menjual ke industri pengolahan. Transaksi jual beli dengan pola ini umumnya dilakukan untuk komoditas ikan-ikan berukuran besar seperti tuna, barakuda, cakalang, lemadang dan ikan karang berukuran besar.

4) Nelayan menjual langsung hasil tangkapan kepada pedagang besar. Transaksi jual beli dengan pola ini umumnya dilakukan untuk komoditas 
ikan-ikan berukuran besar seperti tuna dan ikan-ikan karang berukuran besar.

Seorang nelayan dapat memasarkan komoditas hasil perikanan dengan gabungan dua atau tiga pola pemaran tersebut ketika memperoleh hasil tangkapan dalam berbagai ukuran dan jumlah yang cukup besar serta melimpahnya ikan di pasaran.

\section{KESIMPULAN}

Komoditas perikanan di pulau WangiWangi memiliki nilai ekonomis yang cukup tinggi dan didominasi oleh ikan-ikan pelagis dari famili Scombridae yaitu tuna dan cakalang serta ikan-ikan karang dari famili Lutjanidae, Serranidae dan Haemulidae. Sebagian besar komoditas tersebut diperdagangkan sebagai bahan pangan dalam bentuk segar dan merupakan hasil perikanan tangkap yang ditunjang oleh ekosistem karang dan lamun disekitar pulau. Edukasi terhadap nelayan dan masyarakat di pulau WangiWangi tentang penangkapan yang ramah lingkungan serta upaya pelestarian lingkungan untuk menjaga laut dari kerusakan perlu terus ditingkatkan untuk perikanan yang berkelanjutan. Pengolahan hasil perikanan di Pulau Wangi-Wangi masih terbatas oleh karenanya perlu adanya diversifikasi produk olahan untuk memberikan nilai tambah pada komoditas hasil perikanan yang ada.

\section{UCAPAN TERIMA KASIH}

Penulis mengucapkan terima kasih kepada para pedagang ikan di Pasar Pelangi Marina / Pasar Malam, Pasar Pagi dan Pasar Sentral Wakatobi yang telah memberikan informasi dan bantuannya dalam pengumpulan data untuk penulisan makalah ini.

\section{DAFTAR PUSTAKA}

[1] F. Von Heland and J. Clifton, "Whose Threat Counts? Conservation Narratives in the Wakatobi National Park, Indonesia," Conserv. Soc., vol. 13, no. 2, pp. 154-165, 2015.

[2] J. E. N. VERON et al., "Delineating the Coral Triangle," Galaxea, J. Coral Reef
Stud., vol. 11, no. 2, pp. 91-100, 2009.

[3] A. Ramadhan, L. Lindawati, and N. Kurniasari, "Nilai Ekonomi Ekosistem Terumbu Karang Di Kabupaten Wakatobi," J. Sos. Ekon. Kelaut. dan Perikan., vol. 11, no. 2, p. 133, 2017.

[4] D. J. Smith, "Wakatobi Field Report," University of Essex, Essex, UK, 2006.

[5] R. K. F. Unsworth, L. C. Cullen, J. N. Pretty, D. J. Smith, and J. J. Bell, "Economic and subsistence values of the standing stocks of seagrass fisheries: Potential benefits of nofishing marine protected area management," Ocean Coast. Manag., vol. 53, no. 5-6, pp. 218-224, 2010.

[6] T. C. COREMAPII-LIPI, "Monitoring Ekologi Wakatobi," Jakarta, 2007.

[7] BPS Kab.Wakatobi, Kecamatan WangiWangi Dalam Angka 2018. Wakatobi: BPS Kab. Wakatobi, 2018.

[8] BPS Kab.Wakatobi, Kecamatan WangiWangi Selatan Dalam Angka. Wakatobi: BPS Kab. Wakatobi, 2018.

[9] B. Kab.Wakatobi, Kabupaten Wakatobi Dalam Angka 2018. Wakatobi: BPS Kab. Wakatobi, 2018.

[10] T. Tahara, "Kebangkitan Identitas Orang Bajo di Kepulauan Wakatobi," Antropol. Indones., vol. 34, no. 1, 2013.

[11] E. Suryanegara, Suprajaka, and I. Nahib, "Perubahan Sosial Pada Kehidupan Suku Bajo: Studi Kasus Di Kepulauan Wakatobi , Sulawesi Tenggara ( Social Change on Bajo Tribe : Case Study in Wakatobi Islands , Southeast Sulawesi )," Maj. Globe, vol. 17, no. 1, pp. 67-78, 2015.

[12] Ngadi, "Diversifikasi mata pencaharian dan pendapatan rumah tangga di kawasan pesisir Kabupaten Wakatobi, Sulawesi Tenggara," J. Sos. Ekon. Kelaut. dan Perikan., vol. 11, no. 2, pp. 209-223, 2016.

[13] Halili, "Penilaian Performa Pengelolaan Perikanan menggunakan Indikator EAFM," Wakatobi, 2012.

[14] L. Adam, "Kebijakan Pengembangan Perikanan Berkelanjutan (Studi Kasus: Kabupaten Wakatobi, Provinsi Sulawesi Tenggara dan Kabupaten Pulau Morotai, Provinsi Maluku 
Utara)," J. Perikan. dan Kelaut., vol. II, no. 2, pp. 115-126, 2012.

[15] P. Simonin, "ACSF-Oxfam Rural Resilience Project Case Study: Wakatobi , S . E . Sulawesi, Indonesia," 2014.

[16] R. Rahayu, A. Miftachul Hudha, Sukarsono, and F. Hardian Permana, "Analysis of Nutritional Content of Fresh Sea Worm Honingka (Siphonosoma australe-australe) as a Potential Food Source for Communities," IOP Conf. Ser. Earth Environ. Sci., no. 276, 2019.

[17] Kab.Wakatobi, Buku Profil Perekenomian Kabupaten Wakatobi Tahun 2014. Wakatobi: Pemda Kabupaten Wakatobi, 2016.

[18] W. T. White et al., Market Fishes of Indonesia. Canberra: ACIAR, 2013.

[19] G. Allen, R. Steene, P. Humann, and N. Deloach, Reef Fish Identification Tropical Pacific. El Cajon: New World Publications Inc., 2003.

[20] R. H. Kuiter and T. Tonozuka, Pictoral Guide to: Indonesian Reef Fishes. Zoonetics, 2001.

[21] B. Dharma, Recent and Fossil of Indonesian Shells. Hackenheim: ChonchBooks, 2005.

[22] B. Dharma, Siput Dan Kerang Indonesia I (Indonesian Shells). Jakarta: Sarana Graha, 1988.

[23] B. Dharma, Siput Dan Kerang Indonesia II (Indonesian Shells). Wiesbaden:Verlag Christa Hemmen, 1992.

[24] A. KUSNADI, U. E. Hernawan, and T. Triandiza, Moluska Padang Lamun Kepulauan Kei Kecil. Jakarta: LIPI Press, 2008.

[25] H. Saediman, "Prioritizing commodities in southeast sulawesi province of indonesiausing AHP based borda count method," Asian Soc. Sci., vol. 11, no. 15, pp. 171-179, 2015.

[26] A. Aziz, "Beberapa Catatan Tentang Peikanan Bulu Babi," Oseana, vol. XVIII, no. 2, pp. 65-75, 1993.

[27] P. A. Uneputty, Y. A. Lewerissa, and S. Haumahu, "KERAGAMAN MOLUSKA YANG BERASOSIASI
DENGAN Strombus luhuanus ( Species Diversity of Associated Mollusc to Strombus luhuanus )," J. Trit., vol. 14, no. 2, pp. 50-55, 2018.

[28] A. M. Tapotubun, "Komposisi Kimia Rumput Laut (Caulerpa lentillifera) dari Perairan Kei Maluku dengan Metode Pengeringan Berbeda," J. Pengolah. Has. Perikan. Indones., vol. 21, no. 1, pp. 13-23, 2017.

[29] U. Tangke and S. Deni, "Pemetaan daerah penangkapan ikan madidihang (Thunnus albacares) dan ikan cakalang (Katsuwonus pelamis) di Perairan Maluku Utara," Agrikan J. Ilm. Agribisnis dan Perikan., vol. 6, pp. 117, 2014.

[30] D. Hidayati and L. Rachmawati, Data Dasar Aspek Sosial Terumbu Karang Indonesia. Jakarta: COREMAP-LIPI, 2002.

[31] F. Firmansyah et al., Satu Dekade Pengelolaan Taman Nasional Wakatobi: Keberhasilan dan tantangan konservasi laut. Jakarta: WWF-ID, 2016.

[32] I. Suwandi, "Keberlanjutan Pengelolaan Daerah Perlindungan Laut di Desa Waha Kabupaten Wakatobi," Institut Pertanian Bogor, 2014.

[33] M. Tadjuddah, B. Wiryawan, A. Purbayanto, and E. S. Wiyono, "Analisis Pemetaan Jaringan Perdagangan Ikan Kerapu Hidup Di Taman Nasional Wakatobi, Sulawesi Tenggara, (Mapping Analysis of Life Groupers Trade In Wakatobi Marine National Park Southeast Sulawesi Province, Indonesia)," Bul. PSP, vol. 20, no. 2, pp. 119-130, 2012.

[34] M. Patanda, S. H. Wisudo, D. R. Monintja, and B. Wiryawan, "Sustainability for reef fish resource based on productivity and susceptibility in Wangi-Wangi Island, Southeast Sulawesi, Indonesia," AACL Bioflux, vol. 10, no. 4, pp. 861-874, 2017.

[35] P. A. Uneputty, S. Haumahu, and Y. Lewerissa, "Kemelimpahan dan Distribusi Ukuran Strombus luhuanus Pada Perairan Pantai Berbatu Negeri Oma, Kabupaten Maluku Tengah," in 
Prosiding Simposium Nasional

Kelautan dan Perikanan V Universitas

Hasanuddin, 2018, pp. 209-218.

[36] J. Leiwakabessy and S. Lewerissa, "Amino acid profile of Strombus luhuanus and Lambis lambis from Waisarisa and Suli waters, Maluku Province, Indonesia," AACL Bioflux, vol. 10, no. 5, pp. 1174-1179, 2017.

[37] Furkon, N. Nessa, R. Ambo-Rappe, L. C. Cullen-Unsworth, and R. K. F. Unsworth, "Social-ecological drivers and dynamics of seagrass gleaning fisheries," Ambio, 2019.

[38] W. O. Salma, I. Yusuf, M. Karo, and L. Banudi, "The effect of Sea urchin (Diadema setosum) gonad extract on $\operatorname{IgM}$ and $\mathrm{IgG}$ antibodies production in BALB/c mice infected by Salmonella typhi," J. Gizi Klin. Indones., vol. 14, no. 3, pp. 93-98, 2018.

[39] N. A. Rangka and M. Paena, "Potensi Dan Kesesuaian Lahan Budidaya Rumput Laut (Kappaphycus alvarezii) Di Sekitar Perairan Kabupaten Wakatobi Provinsi Sulawesi Tenggara [Potential And Suitability Of Land Seaweed Farming (Kappaphycus alvarezii) Water Around The District Wakatob," J. Ilm. Perikan. dan Kelaut., vol. 4, no. 2, pp. 151-159, 2019.

[40] M. Jufri, Y. Syaukat, and A. Fariyanti, "Pengaruh Resiko Produksi Terhadap Perilaku Rumah Tangga Petani Rumput Laut Di Kabupaten Wakatobi," J. Ekon. Pertan. dan Agribisnis, vol. 2, no. 5, pp. 443-453, 2018.

[41] C. Nufus, Nurjanah, and A. Abdullah, "Karakteristik Rumput Laut Hijau dari Perairan Kepulauan Seribu dan Sekotong Nusa Tenggara Barat Sebagai Antioksidan," J. Pengolah. Has. Perikan. Indones., vol. 20, no. 3, pp. 620-632, 2017. 